
Institute of Industrial Economics of the NAS of Ukraine 2 Maria Kapnist Street, Kyiv, 03057, Ukraine E-mail: taniakorytko@gmail.com https://orcid.org/0000-0002-4251-1971;

Olena Mykolaivna Kruk,

Phd in Economics, Associate Professor Donbass State Engineering Academy 72 Academic Street, Kramatorsk, 84313, Ukraine E-mail: 1k21061496@gmail.com https://orcid.org/0000-0002-5659-6603

\title{
MODELLING AN IMPACT OF ENTERPRISES' INVESTMENT ACTIVITY ON THE LEVEL OF A REGION'S SUSTAINABLE DEVELOPMENT USING FUZZY LOGIC APPARATUS
}

The paper examines the essence of sustainable development of a region. It has been noted that achievement of sustainable development of a region is possible under the condition of plurality of transformations and changes in enterprises, institutions, organizations, and societies, which operate in the region. The study proves that the assessment of sustainable development of the region, considering the enterprises' investment activity takes into account the following spaces: economic, territorial, administrative, demographic, institutional and organizational ones. Each of the above spaces can be assessed using indicators that characterize the peculiarities of the region.

The objective of the article is to develop a scientific and methodological approach to modeling the impact of enterprises' investment activity on the sustainable development of the region.

The proposed approach to modeling the impact of enterprises' investment activity on the sustainable development of the region allows: to analyze the quantitative indicators of the constituent elements and to define the state and level of development of each element, which significantly improves the efficiency of the necessary organizational support. Testing of the proposed model for assessing the impact of enterprises' investment activity on the sustainable development of the region was demonstrated on the example of Donetsk region.

Based on the apparatus of fuzzy logic, a hierarchical model of assessing the sustainable development of the region takes into account the investment activity of enterprises, which allows the use of expert information about the object of study in the form of logical rules; to synthesize quantitative indicators into a single integrated indicator of structural elements of the system. The advantage of the proposed method is its versatility.

The study shows that during 2018-2020 the level of sustainable development of the Donetsk region based on enterprises' investment activity was satisfactory (0.57). Also, it should be noted that there is a worsening in the value of the indicator, which requires adjustment of strategic guidelines of the region.

Keywords: modeling, sustainability, investment activity, enterprise, development.

JEL: C54; E52; O32; R12

The social and economic component of regional development characterizes the processes that take place with the participation of all subjects of a regional economy, which are aimed at achieving economically feasible results while ensuring stable improvement of the level and quality of life of the population.
Theoretical and practical issues related to the interconnection of interests, goals and objectives of the social and economic development of systems of different levels are of great importance. It should be noted that the "points of economic growth" in the region are enterprises located in its territory. The poten-

(C) T. Yu. Korytko, O. M. Kruk, 2021 
tial of their socio-economic development can be revealed through the synergy of interests of the region and enterprises. The mechanism for achieving this can be modeling an impact of enterprises' investment activity on the sustainable development of the region.

The urgency of enhancing enterprises' investment activity in the region, in particular - in conditions of growing unsustainable market conditions, is obvious, as ensuring the efficiency of their operation and intensification of investment activity is one of the most important functions not only of each enterprise but also the region and the state in general.

In industrial regions, the regional government is interested and ready to assist in the enterprises' upgrading, as it directly faces a lot of problems associated with their low technological level. The use of outdated technologies, physical and moral depreciation of equipment invariably cause a low level of labor productivity, high costs of manufacturing, its low quality, which leads to a decrease in the competitiveness of enterprises in the region. Such enterprises have a negative impact on the environment. All this together affects the level and quality of life of the population, which is a key indicator of the effectiveness of regional authorities. Thus, it can be noted that in modern conditions the emphasis in the transition to investment and innovation development is naturally shifted to the level of regions.

Ensuring balanced social and economic development of regions in dynamic conditions of structural and organizational transformations and uncertainty is an crucial, complex and multifaceted problem, for the effective solution of which it is necessary to use effective means of economic assessment of feasibility, effectiveness and risks of socioeconomic transformations, as well as appropriate means of assessments and regulations, which should include tools for indicative management.

One of the spaces of estimation of sustainability is the calculation of the sustainability index (Environmental Sustainability Index), which was developed and suggested by the Yale and Columbia Universities for World Economic Forum in Davos. On the basis of the calculation there is the index of 22 indica- tors, which are determined by way of averaging 2-5 variables. Totally 67 variables are allocated. When calculating the index value, the significance of all variables is set equal for convenience. It is due to the lack of common essence in environmental problems' ranking.

In 1989, Daly and Cobb (USA) (Daly, 1994) introduced to European countries the method of calculating the index of sustainable economic welfare (Index of Sustainable Economic Welfare). This index is a value, which defines the volume of GDP per capita and is adjusted to the value of costs caused by socioeconomic and environmental factors (Matthews, 2000; Bilan et al., 2017). The development of this index is an attempt to calculate the aggregated monetary index comparable to the existing standards of national accounts and taking into consideration moments that have not been reflected in other approaches due to high aggregation of indicators.

The UN Program of Action "Agenda 21" paragraphs 40.6-7 recommend for countries at the national level, as well as for international governmental and non-governmental organizations at the international level to develop a sustainable concept of development to identify indicators (2007). However, due to the versatility of the indicators and differences in social, economic and environmental conditions the majority of the advanced economies are united in their desire to develop their own indicators and strategies of sustainable development, which are closer to the development of the country.

Sustainable development of the region is characterized by the coordinated development of the economy, society and the environment for the development of the regional economy, improving the life of the population, ensuring the efficient use of resources and preserving the environment ( $\mathrm{Li}, 2018)$. Close cooperation between public and private sectors, as well as non-governmental organizations, has become an important component in the implementation of the sustainable development concept, especially for catching up countries of eastern and central Europe (Gibney, 2014).

The study of sustainability in (Afonso, Jalles, 2015) is proposed to be conducted us- 
ing the public debt ratio. Based on the factors proposed in (Bolívar, 2016), it is offered to define the impact of local governments on the sustainability. A study of regional development policy based on economic issues and decentralization of different levels of government has been proposed in (Bradford, 2013). The paper (Buleev, 2019) pays attention to the development of economic and mathematical model of comprehensive assessment of enterprises' investment activity in the region. An economic-mathematical model that can be used in a generalized form for different countries of the world under the condition of its certain adaptation and detailing of national indicators is proposed in (Garkushenko, 2021). Analysis of the channels linking income distribution, institutional factors, and economic growth have been studied in (Perotti, 1996).

Development and substantiation of methodological support for estimation and forecasting of macroeconomic regulation of development of cascade forms of organization of production-economic, inter-regional and inter-sectoral interaction of regional social and economic systems in Ukraine became the subject of research in (Danylyshyn, 2016). However, in defining the level of the regional socio-economic system development the author does not take into account the impact of the environmental component.

The issues of evaluation the level of a region's development that can be determined by social, economic and environmental factors, as well as the analysis and mechanism of ensuring the economic security of a region, emphasizing the importance of foreign economic security of the region, and using such characteristics as the level of foreign economic openness are dealt in (Herasymchuk, 2002).

The sustainable development of the region is influenced by production and environmental factors (Mishenin et al., 2018), at the same time in (Kyrychenko et al., 2018) is noted that economic growth depends on social factors, moreover - macroeconomic stability is the cause of fast and stable economic growth in East Asian countries (Kuroyanagy et al., 1996).

A peculiarity of the region is its ability to function as a self-developing system, and the sustainability of social and economic development of the region is seen as the antithesis of its crisis in (Uryszek, 2015). Considering sustainability as crisis-free (or secure) development of the territory, and as a basis for strategic analysis of sustainability of territorial development, it is suggested to apply a set of security indicators and sustainable development standards taking into account the main forms of territorial security - economic, social and environmental (Rocchetta, 2019; Vasylenko, 2001).

Economic and mathematical methods are widely used to analyze various economic processes. Social policy determinants are based on the multilevel regression method (Hjerm, 2012; Dion, 2010). The substantiation of indicators characterizing social and economic development but taking into account the correlation between social and economic parameters are offered in (Hrysenko, 2019). Employment of a clustered approach to build a social economy model is suggested in (Stukalo, 2018).

At the same time, despite the significant number of researches on this topic, the relationship between the development of the region on the basis of increasing investment activity of enterprises remains insufficiently studied in theoretical, methodological and applied fields. So, the importance of the issue is related to the role of the investment activity in the sustainable development of the region.

The objective of the paper is to develop a scientific and methodological approach to modeling the impact of enterprises' investment activity on the level of sustainable development of the region based on the fuzzy logic apparatus.

It is proposed to model the sustainable development of the region taking into account the enterprises' investment activity based on the use of the Fishburne rule and the theory of fuzzy sets. In order to assess the effectiveness of the target program as a whole, it is suggested to use an integrated indicator.

Modeling the region's sustainable development on the basis of the enterprises' investment activity will allow regional authorities to evaluate the degree of compliance of the strategic measures with the set goal and 
landmark as well as to identify the need for adjusting strategic management, make timely changes in case of necessity, and develop further steps on the achieving the state of sustainable development. So, a distinctive feature of the suggested methodology is to use a mathematical system for modeling the sus- tainable development of the region on the basis of the investment activity of enterprises.

An algorithm for estimating the impact of the level of the enterprises' investment activity on the sustainable development of the region using a fuzzy logic system is shown in Figure 1.

\section{Stage 1. Methodical tools for modeling sustainable development of the region based on the enterprises' investment activity}

\begin{tabular}{|l|l|}
\hline $\begin{array}{l}\text { 1. Defining the spatial areas of sustainable development of the region taking into ac- } \\
\text { count investment activity of enterprises }\left(I_{i}\right)\end{array}$ \\
$\begin{array}{l}\text { 2. Collection, analysis and processing of the actual data, which form the input infor- } \\
\text { mation to model the sustainable development of the region }\end{array}$ \\
$\begin{array}{l}\text { 3. Formation of a system of indicators for the assessment of spaces of sustainable de- } \\
\text { velopment of the region }\left(x_{j}\right) \text { and their quantitative assessment }\end{array}$ \\
\hline
\end{tabular}

Stage 2. Ranking sustainable development of the region on the basis of enterprises' investment activity

\begin{tabular}{|l|}
\hline 1. Substantiation of term sets' selection \\
\hline $\begin{array}{l}\text { 2. Definition of the basic term-set ( } T \text { ) linguistic variables for selected indicators } \\
\text { importance on forming the } i \text {-th aggregate indicator }(i=1 \ldots z) \text { of a sustainable develop- } \\
\text { ment of the region (II) according to specified spaces }\end{array}$ \\
$\begin{array}{l}\text { 4. Recognition of levels of membership of selected indicators for constructing a mem- } \\
\text { bership function } \mu A(x)\end{array}$ \\
$\begin{array}{l}\text { 5. Construction of classifiers of levels of influential factors for the region's sustainable } \\
\text { development based on the enterprises' investment activity }\end{array}$ \\
vestment activity \\
$\begin{array}{l}\text { 1. Assessment of the affiliation of influential factors of enterprises' investment activity } \\
\text { for sustainable development of the region }\end{array}$ \\
\hline $\begin{array}{l}\text { 2. Defining the level of influence of enterprises' investment activity on the sustainable } \\
\text { development of the region }\end{array}$ \\
\hline
\end{tabular}

Figure 1 - Scientific and methodological approach to modeling the impact of enterprises' investment activity on the sustainable development of the region using the apparatus of fuzzy logic

Source: developed by authors.

At the first stage for modeling methodical tools for estimation of the region's sustainable development on the basis of the en- terprises' investment activity are proposed. The indicators are based on the expert method in accordance with the areas characterizing the 
sustainable development of the region. When using this method, an expert has a task - to assess the qualitative property of the criterion in points (pre-set range of changes in this assessment). Experts should reflect the degree of conformity of the variant of the considered property.

It should be noted that the complexity of the formation of the estimation information base of the sustainable development of the region based on the investment activity of enterprises lies in:

its diversity, associated with the implementation of various types of activity at the regional level;

different terms and conditions of formation of information in subsystems: accounting, financial, management (production) statements;

the difference of the target orientation of the generated information: in time (regarding activities in previous reporting periods, current activities, activities in perspective), in fields of use (in planning, analysis etc.), for entering information on the number of objects, etc.;

possibilities of systematization and processing of information by means of professional, local, common and standardized computer programs and databases (Ershova, 2016; Astapova et al., 2015).

All selected indices have different measurement units, so the expedient conduct of the matching operations between them led to their standardization using a linear scaling method (Spiridonova, 2010; Makarkina, 2011). With this method, the value of each indicator is aggregated in the range from 0 to 1 .

At this stage, aggregate indicators for each space are combined using a geometric mean. In order to assess the sustainable development of the region on the basis of enterprises' investment activity was conducted a convolution of all private indicators with the appropriate weight for each space. As a weight, authors chose a matrix consisting of two types of scales, defined by the Fishburne rule and on the basis of fuzzy set theory.

According to Fishburne's rule, it is necessary to compare each indicator of the corresponding space $C_{j}$ with the level of its significance ri. and evaluate it by arranging all indi- cators in descending order of significance so, that the rule is fulfilled: $r_{1} \geq r_{2} \geq \ldots \geq r_{n}$ (Nedosekin, 2003).

For the region, the level of significance of all spaces shall be taken to be the same, then the coefficient $r_{i}$. at calculations is $1 / \mathrm{N}$.

To define the second type of space weights, the following will be introduced:

1) the fuzzy set $A_{i}\{i=1,5\}$, which characterizes the belonging of the level of sustainable development of the region in accordance with the specified spaces $C_{j}$, is divided into five subsets of states:

$A_{1}$ - fuzzy subset of «very low level of sustainable development»;

$A_{2}$ - fuzzy subset of «low level of sustainable development»;

$A_{3}$ - fuzzy subset of «satisfactory level of sustainable development»;

$A_{4}$ - fuzzy subset of «high level of sustainable development»;

$A_{5}$ - fuzzy subset of «very high level of sustainable development».

The carrier of the set $A_{i}$ takes on values in the range from 0 to 1 in accordance with the suggested method of closing up of the parameters of the spaces $C_{j}$;

2) Further, in accordance with the formed set $A$, a complete set of levels of the enterprises' investment activity $G$ is divided into five subsets:

$G_{1}$ - fuzzy subset of «very low level of the enterprises' investment activity»;

$G_{2}$ - fuzzy subset of «low level of the enterprises' investment activity»;

$G_{3}$ - fuzzy subset of «satisfactory level of the enterprises' investment activity»;

$G_{4}$ - fuzzy subset of «high level of the enterprises' investment activity»;

$G_{5}$ - fuzzy subset of «a very high level of investment activity enterprises».

The carrier of the set $G$ is an indicator of the level of the sustainable development of the region on the basis of the enterprises' investment activity $g$ - acquires a value from 0 to 1 by definition.

Describing the type of subsets of the term-set, a system of five features of affiliation is introduced that characterize the degree of affiliation of the segment values of the 01medium to a given subset (Tab. 1). 
Table 1 - Classification of the level of a region's sustainable development based on the enterprises' investment activity

\begin{tabular}{|c|c|c|}
\hline Value interval G & $\begin{array}{c}\text { Classification of the } \\
\text { parameter's level }\end{array}$ & $\begin{array}{c}\text { The degree of confidence } \\
\text { (independence function) }\end{array}$ \\
\hline $0<g<0.15$ & $G_{5}$ & 1 \\
\hline \multirow{2}{*}{$0.15<g<0.25$} & $G_{5}$ & $\mu_{5}=10 \cdot(0.25-g)$ \\
\hline $0.25<g<0.35$ & $G_{4}$ & $1-\mu_{5}=\mu_{4}$ \\
\hline \multirow{2}{*}{$0.35<g<0.45$} & $G_{4}$ & 1 \\
\hline $0.45<g<0.55$ & $G_{4}$ & $\mu_{4}=10 \cdot(0.45-g)$ \\
\hline \multirow{2}{*}{$0.55<g<0.65$} & $G_{3}$ & $1-\mu_{4}=\mu_{3}$ \\
\hline $0.65<g<0.75$ & $G_{3}$ & $\mu_{3}=10 \cdot(0.65-g)$ \\
\hline \multirow{2}{*}{$0.75<g<0.85$} & $G_{3}$ & $1-\mu_{3}=\mu_{2}$ \\
\hline $0.85<g<1$ & $G_{2}$ & 1 \\
\hline & $G_{2}$ & $\mu_{2}=10 \cdot(0.85-g)$ \\
\hline
\end{tabular}

Source: Compiled by authors.

3) for the indicators of spaces $C \mathrm{j}$ the following set of its values $B_{j}$ is defined, which is also splits into five subsets: dex;

$B_{1}$ - subset of a very low level of $C_{j}$ in-

$B_{2}$ - subset of a low level of $C_{j}$ index; index;

$B_{3}$ - subset of a satisfactory level of $C_{j}$

$B_{4}$ - subset of a high level of $C_{j}$ index;

$B_{5}$ - subset of a very high level of $C_{j}$ index.

Then, the affiliation function corresponds to each indicator $C_{j}$ that matches the accessory $\mu_{i, j}\left(C_{j}\right)\{j=1,5\}$, which reflects the degree of affiliation of the space index of a subset $A_{i}$, values of which lie in the range from 0 to 1 .

The next step is to build the function of the accessory $\mu_{i, j}\left(C_{j}\right)$ for each linguistic term from the basic term set $T$.

The function $\mu_{i, j}\left(C_{j}\right)$ is a mathematical function that defines the probability and in which elements of a certain set $C$ belong to a given fuzzy set $A$ - the main tool of the formalism of fuzzy logic. The more the argument $C$ corresponds to the fuzzy set A, the greater the value of $\mu_{i, j}\left(C_{j}\right)$ is. That is, the closer the value of the argument is to 1 (Kotenko et al., 2020).

It is offered to use the function of affiliation of fuzzy set of the trapezoidal shape that allows specifying cores of the fuzzy set and uniquely characterizes the affiliation of this indicator to the fuzzy infinity $A_{i}$. The trapezoidal shape of the fuzzy set can be represented in the following form:

$$
\left\{\begin{array}{l}
0, \quad x \prec a ; \\
\frac{x-a}{b-a}, a \leq x \leq b ; \\
1, b \leq x \leq c ; \\
\frac{d-x}{d-c}, c \leq x \leq d ; \\
0, \quad b \leq x,
\end{array}\right.
$$

where: $[a, d]$ is a fuzzy set containing a pessimistic estimate of the variable values; $[b, c]$ is the core of a fuzzy set containing an optimistic estimate of the variable values.

In the trapezoidal function of affiliation to each fuzzy subset $B_{j}$, one can identify the cores, where this function takes the value equal to 1 .

On the basis of the calculated weight of the Fisherburn's, the values of the nodal points $\beta_{j}$ and values of functions of affiliation $\mu_{i}$, $j\left(C_{j}\right)$, the transformation matrix of two systems of weights is formed: $\lambda_{j}=r_{i} \cdot \beta_{j} \cdot \mu_{i, j}(C j)$.

Having defined the transformation matrix of two types of weights for each space, at the third stage the level of the impact of the enterprises' investment activity on the sustainable development of the region is determined. It is defined as the closing up of all the parameters of spaces with the corresponding magnitude of the weight matrix by each space: 


$$
g=\sum_{j=1}^{5} g_{j} \sum_{i=1}^{N} r_{i} l_{i j}
$$

where: $g_{j}=0.9-0.2(j-1) ; r_{i}$ - weight factor of the $i$-indicator; $\lambda$ - level of the carrier's affiliation to a fuzzy subset.

The final step is to rank the regions by the level of the sustainable development based on the enterprises' investment activity in order to create a rating for the analytical analysis of the received results. The degree of affiliation of each of comparable structures to the criteria defined on the basis of the Harrington verbal-numerical scale, which includes meaningfully described names of graduations and the corresponding ranges of numerical values (Table 2).

\section{Table 2 - The level of sustainable development of the region on the basis of the enterprises' investment activity}

\begin{tabular}{|c|c|}
\hline Interval & $\begin{array}{c}\text { The level of sustainable development of the region } \\
\text { on the basis of enterprises' investment activity }\end{array}$ \\
\hline $0-0.2$ & Very low \\
\hline $0.2-0.4$ & Low \\
\hline $0.4-0.6$ & Satisfactory \\
\hline $0.6-0.8$ & High \\
\hline $0.8-1$ & Very high \\
\hline
\end{tabular}

Source: Compiled by authors.

The result of the classification is a linguistic description of the impact of the enterprises' investment activity on the sustainable development of the region, as well as the degree of confidence of the expert in the correctness of the classification. Thus, the conclusion about the degree of influence of investment activity of enterprises on sustainable development of the region obtains not only a linguistic form, but also quality characteristics of the received statements.
Further is made an assessment of the impact of enterprises' investment activity on the level of sustainable development of the region on the basis of the suggested scientific and methodological approach. The normalized values of the indicators used in modeling the impact of enterprises' investment activity on the level of sustainable development of the region are given in table 3 .

The results of the experts' survey and the subsequent obtained calculations are shown in Table 4.

Table 3 - Normative values of indicators of the estimation of impact of the enterprises' investment activity on the level of sustainable development of the Donetsk region

\begin{tabular}{|c|l|c|c|c|}
\hline \multirow{2}{*}{ Space } & \multicolumn{1}{|c|}{$\begin{array}{c}\text { Indicators that characterize the impact } \\
\text { on the management process }\end{array}$} & 2018 & $2019 *$ & 2020 \\
\hline 1 & \multicolumn{1}{|c|}{2} & 3 & 4 & 5 \\
\hline \multirow{5}{*}{$\begin{array}{l}\text { Economic } \\
(C 1)\end{array}$} & $\begin{array}{l}\text { 1. Industrial production index, to the relevant period the } \\
\text { previous year }\end{array}$ & 0.4324 & 0.6714 & 0.7010 \\
\cline { 2 - 5 } & 2. Agricultural indexes of products in to the previous year & 0.3896 & 0.5687 & 1.0000 \\
\cline { 2 - 5 } & 3. Capital investment & 0.3676 & 0.7279 & 0.8456 \\
\cline { 2 - 5 } & 4. Investments in the economy of the region & 0.9361 & 0.9652 & 0.9433 \\
\cline { 2 - 5 } & 5. Net profit (loss) & 0.4366 & 0.7930 & 0.9907 \\
\cline { 2 - 5 } & 6. Consumer price indices for goods and services & 0.9641 & 0.5264 & 0.0000 \\
\hline \multirow{3}{*}{$\begin{array}{l}\text { Territorial } \\
(C 2)\end{array}$} & 1. Territory & 1.0000 & 1.0000 & 1.0000 \\
\cline { 2 - 5 } & 2. Population & 0.0000 & 0.0000 & 0.0000 \\
\cline { 2 - 6 } & $\begin{array}{l}\text { 3. Coefficient of environmental sustainability of the terri- } \\
\text { tory }\end{array}$ & 0.9767 & 0.9767 & 0.9767 \\
\hline
\end{tabular}


End of table 3

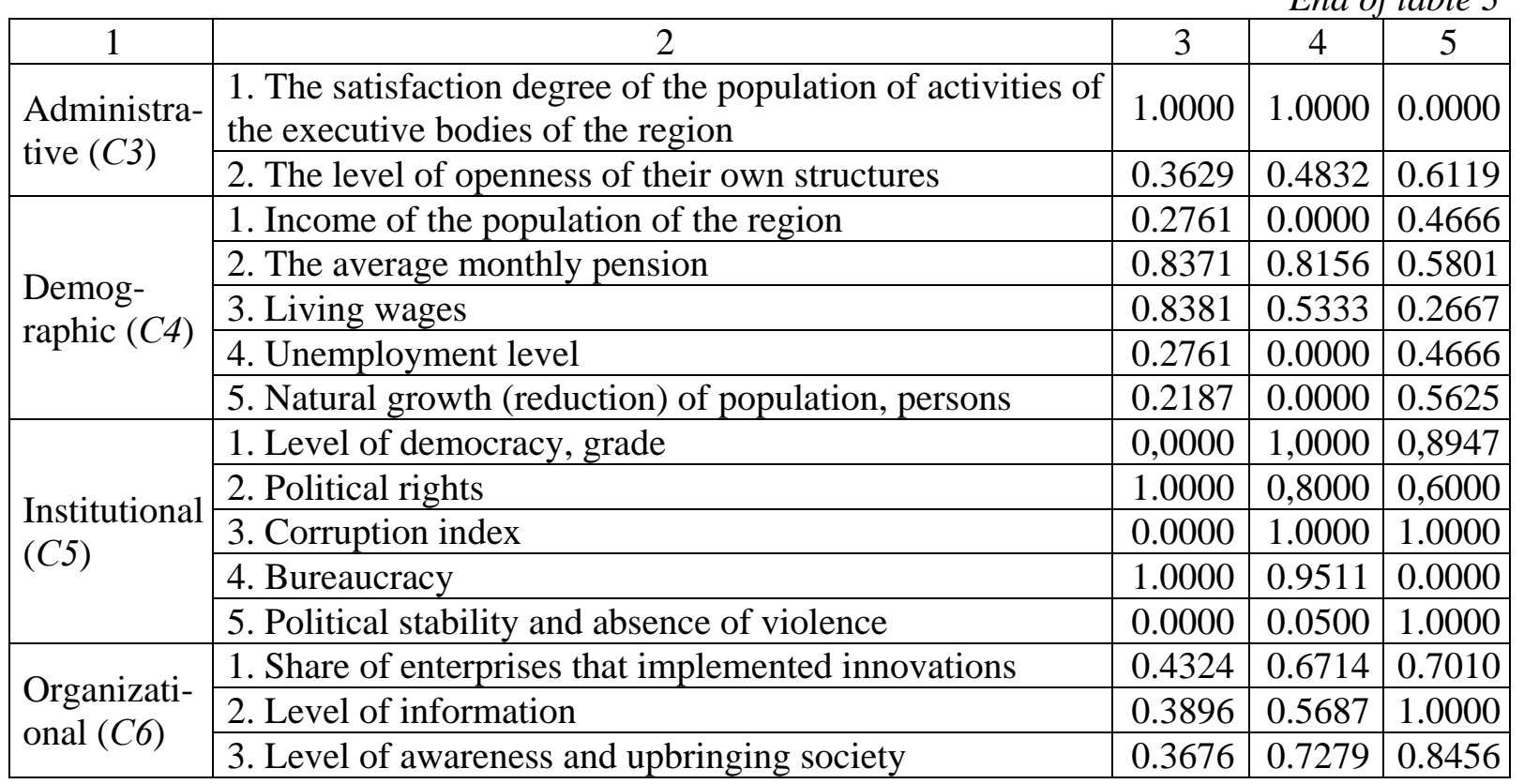

Source: calculated according to statistical data of Donetsk, Luhansk, Kharkiv, Zaporizhia regions.

Table 4 - Value intervals for the indicators of spaces

\begin{tabular}{|c|c|c|c|c|c|}
\hline \multirow{2}{*}{$\begin{array}{c}\text { Indicators which characterize } \\
\text { the impact on sustainable } \\
\text { development of the region }\end{array}$} & $\begin{array}{c}\text { Very } \\
\text { low }\end{array}$ & Low & satisfactory & high & $\begin{array}{c}\text { Very } \\
\text { high }\end{array}$ \\
\cline { 2 - 6 } & {$[0 ; 0.2]$} & {$[0.1 ; 0.3]$} & {$[0.25 ; 0.5]$} & {$[0.45 ; 0.7]$} & {$[0.6 ; 1]$} \\
\hline$X_{1}$ & {$[0 ; 0.3]$} & {$[0.35 ; 0.53]$} & {$[0.6 ; 0.72]$} & {$[0.7 ; 0.83]$} & {$[0.8 ; 1]$} \\
\hline$X_{2}$ & {$[0 ; 0.25]$} & {$[0.2 ; 0.55]$} & {$[0.45 ; 0.65]$} & {$[0.65 ; 0.85]$} & {$[0.9 ; 1]$} \\
\hline$X_{3}$ & {$[0 ; 0.25]$} & {$[0.2 ; 0.48]$} & {$[0.4 ; 0.65]$} & {$[0.66 ; 0.7]$} & {$[0.76 ; 1]$} \\
\hline$X_{4}$ & {$[0 ; 0.03]$} & {$[0.25 ; 0.45]$} & {$[0.38 ; 0.45]$} & {$[0.55 ; 0.7]$} & {$[0.8 ; 1]$} \\
\hline$X_{5}$ & {$[0 ; 0.14]$} & {$[0.12 ; 0.2]$} & {$[0.18 ; 0.4]$} & {$[0.3 ; 0.8]$} & {$[0.69 ; 1]$} \\
\hline$X_{6}$ & {$[0 ; 0.05]$} & {$[0.03 ; 0.3]$} & {$[0.25 ; 0.5]$} & {$[0.45 ; 0.7]$} & {$[0.6 ; 1]$} \\
\hline$X_{7}$ & {$[0 ; 0.25]$} & {$[0.3 ; 0.43]$} & {$[0.5 ; 0.72]$} & {$[0.6 ; 0.83]$} & {$[0.8 ; 1]$} \\
\hline$X_{8}$ & {$[0 ; 0.25]$} & {$[0.2 ; 0.55]$} & {$[0.45 ; 0.65]$} & {$[0.65 ; 0.85]$} & {$[0.9 ; 1]$} \\
\hline$X_{9}$ & {$[0 ; 0.25]$} & {$[0.2 ; 0.38]$} & {$[0.35 ; 0.48]$} & {$[0.44 ; 0.6]$} & {$[0.56 ; 1]$} \\
\hline$X_{10}$ & {$[0 ; 0.3]$} & {$[0.2 ; 0.45]$} & {$[0.4 ; 0.65]$} & {$[0.6 ; 0.85]$} & {$[0.8 ; 1]$} \\
\hline$X_{11}$ & {$[0 ; 0.24]$} & {$[0.2 ; 0.42]$} & {$[0.5 ; 0.6]$} & {$[0.65 ; 0.8]$} & {$[0.75 ; 1]$} \\
\hline$X_{12}$ & {$[0 ; 0.2]$} & {$[0.18 ; 0.35]$} & {$[0.3 ; 0.55]$} & {$[0.5 ; 0.78]$} & {$[0.75 ; 1]$} \\
\hline$X_{13}$ & {$[0 ; 0.55]$} & {$[0.5 ; 0.63]$} & {$[0.55 ; 0.72]$} & {$[0.7 ; 0.83]$} & {$[0.8 ; 1]$} \\
\hline$X_{14}$ & {$[0 ; 0.25]$} & {$[0.2 ; 0.55]$} & {$[0.45 ; 0.65]$} & {$[0.6 ; 0.805]$} & {$[0.85 ; 1]$} \\
\hline$X_{15}$ & {$[0 ; 0.25]$} & {$[0.2 ; 0.38]$} & {$[0.35 ; 0.5]$} & {$[0.54 ; 0.76]$} & {$[0.73 ; 1]$} \\
\hline$X_{16}$ & {$[0 ; 0.3]$} & {$[0.25 ; 0.45]$} & {$[0.4 ; 0.65]$} & {$[0.55 ; 0.78]$} & {$[0.75 ; 1]$} \\
\hline$X_{17}$ & {$[0 ; 0.14]$} & {$[0.12 ; 0.32]$} & {$[0.3 ; 0.64]$} & {$[0.6 ; 0.78]$} & {$[0.7 ; 1]$} \\
\hline$X_{18}$ & {$[0 ; 0.25]$} & {$[0.2 ; 0.55]$} & {$[0.45 ; 0.65]$} & {$[0.65 ; 0.85]$} & {$[0.9 ; 1]$} \\
\hline$X_{19}$ & {$[0 ; 0.25]$} & {$[0.2 ; 0.38]$} & {$[0.35 ; 0.58]$} & {$[0.54 ; 0.76]$} & {$[0.86 ; 1]$} \\
\hline$X_{20}$ & {$[0 ; 0.3]$} & {$[0.27 ; 0.45]$} & {$[0.4 ; 0.68]$} & {$[0.65 ; 0.8]$} & {$[0.77 ; 1]$} \\
\hline$X_{21}$ & {$[0 ; 0.2]$} & {$[0.1 ; 0.3]$} & {$[0.25 ; 0.5]$} & {$[0.45 ; 0.7]$} & {$[0.6 ; 1]$} \\
\hline$X_{22}$ & & & &
\end{tabular}

Source: calculated by authors.

Економіка промисловості (뵤) Economy of Industry 
Then fuzzy logic equations are used to calculate the value of the output parameter for fixed values of the input parameters. The equations are obtained from fuzzy logical statements, replacing the terms of the linguistic variables with the corresponding functions of affiliation, and the operations «and» and «or» - with the operations finding minimum (A) and maximum (V) correspondingly.

As the result of working out the rules and carrying out operations on fuzzy sets an integral estimate of the impact of the enterprises' investment activity on sustainable development of the region, expressed by a clear number, will be obtained. Based on the received data the integral estimation of the im- pact of the enterprises' investment activity on sustainable development of the region can be concluded regarding the linguistic state of the variable $X_{1}$ «Industrial production index» for the activation of innovation activity of enterprises (very low, low, less satisfactory, high, very high).

Figure 2 shows an example of the affiliation function $\mu A 1-A 6(C)$ of the linguistic variable $X_{4}$ «Investments in the economy of the region».

It is necessary to classify the obtained value of the level of sustainable development of the region of the enterprises' investment activity according to the database (table 5).

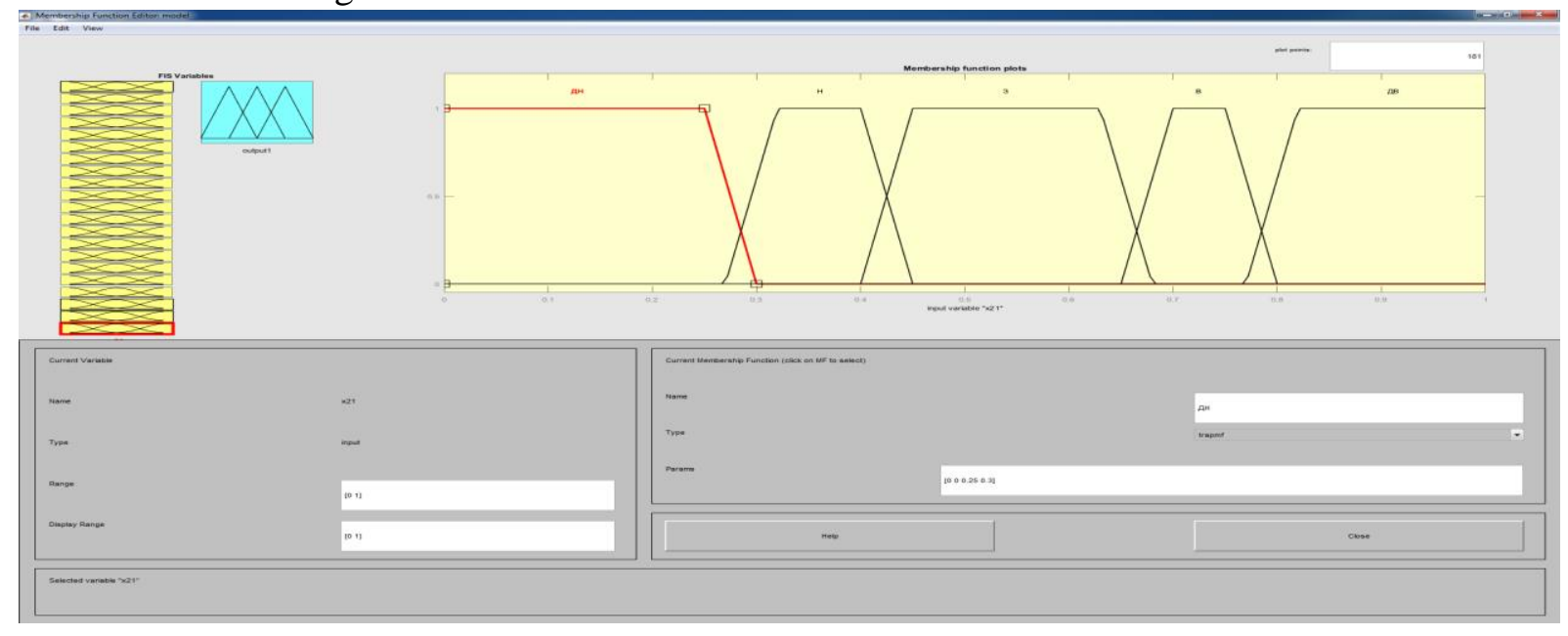

Figure 2 - Schedule of the affiliation function for the integral variable Index of the impact of Source: calculated by authors. the enterprises' investment activity on sustainable development of the region

Table 5 - The level of sustainable development of the region considering the impact of the enterprises' investment activity of Donetsk region

\begin{tabular}{|c|c|c|l|}
\hline Year & $\begin{array}{c}\text { Value of the indicator } \\
\mathrm{X}_{4} \text { «Investments in the } \\
\text { economy of the region» }\end{array}$ & $\begin{array}{c}\text { Calculated values of } \\
\text { the resulting integral } \\
\text { indicator (Y) }\end{array}$ & $\begin{array}{c}\text { The level of sustainable development } \\
\text { of the region considering the impact } \\
\text { enterprises' investment activity }\end{array}$ \\
\hline 2017 & 0,7661 & 0,62 & $\begin{array}{l}\text { Satisfactory level of sustainable develop- } \\
\text { ment of the region based on the invest- } \\
\text { ment activity of enterprises }\end{array}$ \\
\hline 2018 & 0,8306 & 0,64 & $\begin{array}{l}\text { Satisfactory level of sustainable develop- } \\
\text { ment of the region based on the invest- } \\
\text { ment activity of enterprises }\end{array}$ \\
\hline 2019 & 0,9113 & 0,69 & $\begin{array}{l}\text { Satisfactory level of sustainable develop- } \\
\text { ment of the region based on the invest- } \\
\text { ment activity of enterprises }\end{array}$ \\
\hline
\end{tabular}

Source: compiled by authors. 
The results obtained on the basis of the developed scientific and methodological approach to modeling the impact of enterprises' investment activity on the level of sustainable development of the region show that in 20182020 the level of sustainable development in Donetsk region can be considered a satisfactory one.

The results of the modeling of the impact of the enterprises' investment activity on sustainable development of the region has shown that the application of the method of fuzzy sets gives an opportunity to objectively estimate the level of development, as it takes into account qualitative changes and it allows to identify the problem areas of the region's activity that require improvement or reform.

Conclusions. The study develops a scientific and methodological approach to modeling the impact of enterprises' investment activity on the level of sustainable development of the region on the base of fuzzy logic using the package Fuzzy Logic Toolbox of the Matlab software.

The modeling of sustainable development of the region with the enterprises' investment activity is carried out taking into account the following spaces: economic, territorial, administrative, demographic, institutional, organizational. Each of the above fields can be assessed with application of indicators that characterize the region's peculiarities.

The suggested scientific and methodological approach to modeling the impact of enterprises' investment activity on the level of sustainable development of the region allows: to analyze quantitative indicators of components, define the state and level of development of each element, which significantly improves the efficiency of the necessary organizational support. This scientific and methodological approach does not involve establishing a relationship between the factors and the final variable from previous data. This function is performed by a set of rules. Indicators can be added to or excluded from the knowledge base. It also provides clear and convincing comparison results.

The practical implementation of the suggested scientific and methodological approach to modeling the impact of enterprises' investment activity on the level of sustainable development of the region was carried out on the example of the Donetsk region. The results of the study show that during 2018-2020 the level of sustainable development of the Donetsk region based on enterprises' investment activity was satisfactory. But it should be noted that there is a worsening in the value of the indicator, which requires adjustment of strategic guidelines for regional development. Prospects for further research include the development of an algorithm for the formation and implementation of investment development policy in the region.

\section{Література}

Астапова Х. В., Ареф'єва О. В., Матвєєв В. В. (2015). Фінансова діяльність та корпоративна стратегія комериійних банків. Київ: Центр учбової літератури. 128 с.

Василенко В. (2001). Критерії якості та перехід суспільства до сталого розвитку. Стандарти та якість. № 3. С. 24-32.

Гаркушенко О. М. (2021). Системно-динамічна модель оцінки впливу цифровізації на сталий розвиток. Економіка промисловості. № 1 (93). C. 20-45. DOI: http://doi. org/10.15407/econindustry2021. 01.020

Герасимчук 3. В., Вахович I. М. (2002). Opганізачійно-економічний механізм формування та реалізації стратегіï розвитку регіону. Луцьк: ЛІТТУ. 242 с.

Грисенко М., Приятельчук О., Шворак Л. (2019). Моделювання державних соціально-економічних систем у країнах європейського регіону. Проблеми та перспективи управління. № 17 (3). С. 452-463.

Данилишин Б., Микитенко В. (2016). Визначення ефективності макроекономічного регулювання розвитку каскадів регіональних соціально-економічних систем у обмеженнях джерел ресурсів. Економіка. Управління. Інновачії. № 3 (18). URL: http://nbuv. gov.ua/UJRN/eui_2016_ 3_5 (дата звернення: 11.09.2021).

Єршова Н. Ю. (2016). Методологічний підхід до оцінки стратегічної стабільності підприємств на основі інформаційної платформи стратегічного управлінського обліку. Економічний аналіз. № 23 (2). C. 51-59. 
Кириченко К. І., Самусевич Ю. В., Люлова Л. Ю., Багмет К. (2018). Інновації в оцінці рівня соціального розвитку країни. Маркетинг та управління інновачіями. № 2. C. 113-128. DOI: https://doi.org/ 10.21272/mmi.2018.2-10

Котенко С., Ніценко В., Ганжуренко I., Гавриш В. (2020). Етапи математичного моделювання поєднання перевезення вантажів для невизначених, нечітких та стохастичних параметрів. Міжнародний журнал інтегрованої інженерії. № 12 (7). С. 173-180.

Макаркіна Х. В., Івченкова О. Ю. (2011). Оцінка ефективності системи та невідповідних серцевих каналів у свідомості інформації, що не має цінності. Бізнес Інформ. № 7 (1). С. 111-114.

Мішенін Ю., Коблінська І., Медвідь В. та Майстренко Ю. (2018). Формування політики сталого регіонального розвитку: роль промислової екології та логістики. Підприємництво та питання сталого розвитку. № 6 (1). С. 329-341.

Недосекин А. О. (2003). Методологические основы моделирования финансовой деятельности с использованием нечеткократных описаний. СПб. 100 с.

Спиридонова С. П. (2010). Показники якості життя та методології їх формування. Питання сучасної науки та практики. № 10-12 (31). С. 208-223.

Стукало Н., Сімахова А. (2018). Глобальні параметри кластеризації соціальної економіки. Проблеми та перспективи управління. № 16 (1). С. 36-47. DOI: http://doi.org/10.21511/ppm.16(1).2018.04

Afonso A., Jalles T. (2015). Fiscal sustainability: a panel assessment for advanced economies. Applied Economics Letters. Vol. 22 (11). P. 925-929. DOI: https://doi.org/10. 32782/2524-0072/2019-20-15

Bolívar M., Galera A., Muñoz L., Subires M (2016). Analyzing forces to the financial contribution of local governments to sustainable development. Sustainability. Vol. 8 (9). P. 925. DOI: https://doi.org/10. 3390/su8090925

Bradford N., Wolfe D. (2013). Governing regional economic development: innovation challenges and policy learning in Canada.
Cambridge Journal of Regions Economy and Society. Vol. 6 (2). P. 331-347. DOI: https://doi.org/10.1093/cjres/rst006

Buleev I. P., Bryukhovetskaya N. Ye., Korytko T. Yu., Kruk O. N. (2019). Formation of a Regional Development Strategy According to the Level of Investment. Montenegrin Journal of Economics. Vol. 15(3), P. 113-124. DOI: https://doi.org/10.14254/ 1800-5845/2019.15-3.8

Daly H. E., Cobb J. (1994). For the Common Good: Redirecting the Economy Toward Community, the Environment, and a Sustainable Future. Beacon Press, Boston, MA. 520 p.

Dion M., Birchfield V. (2010). Economic development, income inequality, and preferences for redistribution. International. Studies Quarterly. Vol. 54(2). P. 315-344.

Gibney J. (2014). Don't lose sight of context: A commentary on mobilising cities and regions. Regional Studies, Regional Science. Vol. 1. P. 25-27.

Hjerm M., Schnabel A. (2012). How much heterogeneity can the welfare state endure? The influence of heterogeneity on attitudes to the welfare state. Nations and $\mathrm{Na}$ tionalism. Vol. 18(2). P. 346-369. DOI: https://doi.org/10.1111/j.1469-8129.2011. 00523.x

Kuroyanagi M., Yano J., Nakanishi Y., Komatsu M., Futamura H., Mihira T. (2016). Macroeconomic Stabilisation and Monetary Policy of Four Asian Countries: Japan, Korea, Indonesia, and the Philippines. Targets, Effectiveness and Results. Economic Analysis series. Vol. 145. P. 81. DOI: http://doi.org/10.21272/mmi.2018.2-10

Li F., G. Li, W. Qin, J. Qin, H. Ma (2018). Identifying Eco-nomic Growth Convergence Clubs and Their Influencing Factors in China. Sustainability. Vol. 10(8). P. 2588. DOI: http://doi.org/10.3390/su100 82588

Matthews J., Munday M., Roberts A., Williams A., Christie M., Midmore P. (2003). An Index of Sustainable Economic Welfare for Wales: 1990-2000. Cardiff: Cardiff Business School. 73 p.

Perotti R. (1996). Growth, Income Distribution, and Democracy: What the Data Say. 
Journal of Economic Growth. Vol. 1(2), P. 149-187. DOI: http://doi.org/10.1007/ BF00138861

Rocchetta S., Mina A. (2019). Technological coherence and the adaptive resilience of regional economies. Regional Studies. Vol. 53(10). P. 1421-1434. DOI: http://doi. org/10.1080/00343404.2019.1577552

Uryszek T. (2015) Sustainable public finance - illusion or reality? Evidence from old EU member states. Journal of International Studies. Vol. 8(1). P. 22-30.

\section{References}

Astapova, H. V., Arefieva, O. V., \& Matveev, V. V. (2015). Financial activity and corporate strategy of commercial banks. Kiev. 128 p. [in Ukrainian]

Vasilenko, V. (2001). Quality criteria and society's transition to sustainable development. Standards and quality, 3, pp. 24-32. [in Ukrainian].

Garkushenko, O. M. (2021). System-dynamic model for assessing the digitalization impact on sustainable development. Econ. promisl., 1 (93), pp. 20-45. DOI: http://doi. org/10.15407/econindustry2021. 01.020 [in Ukrainian]

Herasymchuk, Z. V., \& Vakhovych, I. M. (2002). Organizational and economic mechanism of formation and implementation of the development strategy of the region. Lutsk: LITTU. [in Ukrainian]

Hrysenko, M., Pryiatelchuk, O., \& Shvorak, L. (2019). Modeling of state socio-economic systems in the countries of the European region. Problems and Perspectives in Management, 17(3), pp. 452-463 [in Ukrainian].

Danylyshyn, B., \& Mykytenko, V. (2016). Determination of the effectiveness of macroeconomic regulation of development of the cascades of the regional socioeconomic systems in re-source restrictions. Economy. Management. Innovations, 3(18). Retrieved from http://nbuv.gov.ua/UJRN/eui_ 2016_3_5 [in Ukrainian].

Ershova, N. Yu. (2016). Methodological approach for the evaluation of the strategic stability of enterprises on the basis of information platform of strategic manage- ment accounting. Ekonomichnyy analiz, 23(2), pp. 51-59 [in Ukrainian].

Kyrychenko, K. I., Samusevych, Y. V., Liulova, L. Y., \& Bagmet, K. (2018). Innovations in country's social development level estimation. Marketing and Management of Innovations, 2, pp. 113-128 DOI: https://doi. org/10.21272/mmi.2018.2-10 [in Ukrainian].

Kotenko, S., Nitsenko, V., Hanzhurenko, I., \& Havrysh, V. (2020). The Mathematical Modeling Stages of Combining the Carriage of Goods for Indefinite, Fuzzy and Stochastic Parameters. International Journal of Integrated Engineering, 12 (7), pp. 173-180 [in Ukrainian].

Makarkina, H. V., \& Ivchenkova, O. Yu. (2011). Evaluation of the efficiency of the system and non-compliant cardiac outlets in the minds of information non-value. Business Inform, 7 (1), pp. 111-114 [in Ukrainian].

Mishenin, Y., Koblianska, I., Medvid, V., \& Maistrenko, Y. (2018). Sustainable regional development policy formation: role of industrial ecology and logistics. Entrepreneurship and Sustainability, 6 (1), pp. 329341 [in Ukrainian].

Nedosekin, A. O. (2003). Methodological foundations for modeling financial activities using fuzzy-multiple descriptions. SPb. 100 p. [in Russian].

Spiridonova, S. P. (2010). Life quality indicators and methodologies for their formation. Questions of modern science and practice, 10-12 (31), pp. 208-223 [in Ukrainian].

Stukalo, N., \& Simakhova, A. (2018). Global parameters of social economy clustering. Problems and Perspectives in Management, 16 (1), pp. 36-47. DOI: http://doi.org/10.21 511ppm.16(1).2018.04 [in Ukrainian].

Afonso, A., \& Jalles, T. (2015). Fiscal sustainability: a panel assessment for advanced economies. Applied Economics Letters, 22 (11), pp. 925-929. DOI: https://doi.org/ 10.32782/2524-0072/2019-20-15

Bolívar, M. P. R., Galera, A. N., Muñoz, L. A., \& Subires, M. D. L. (2016). Analyzing forces to the financial contribution of local governments to sustainable development. Sustainability, $8(9)$, pp. $925 . \quad$ DOI: https://doi.org/10.3390/su8090925 
Bradford, N., \& Wolfe, D. A. (2013). Governing regional economic development: innovation challenges and policy learning in Canada. Cambridge Journal of Regions Economy and Society, 6 (2), pp. 331-347. DOI: https://doi.org/10.1093/cjres/rst006

Buleev, I. P., Bryukhovetskaya, N. Ye., Korytko, T. Yu., \& Kruk, O. N. (2019). Formation of a Regional Development Strategy According to the Level of Investment. Montenegrin Journal of Economics, 15 (3), pp. 113-124. DOI: https://doi.org/10.142 54/1800-5845/2019.15-3.8

Daly, H. E., \& Cobb, J. (1994). For the Common Good: Redirecting the Economy Toward Community, the Environment, and a Sustainable Future. Beacon Press, Boston, MA.

Dion, M. L., \& Birchfield, V. (2010). Economic development, income inequality, and preferences for redistribution. International. Studies Quarterly, 54 (2), pp. 315-344.

Gibney, J. (2014). Don't lose sight of context: A commentary on mobilising cities and regions. Regional Studies, Regional Science, 1, pp. 25-27.

Hjerm, M., \& Schnabel, A. (2012). How much heterogeneity can the welfare state endure? The influence of heterogeneity on attitudes to the welfare state. Nations and Nationalism, 18 (2), pp. 346-369. DOI: https://doi.org/10.1111/j.1469-8129.2011. 00523.x
Kuroyanagi, M., Yano, J., Nakanishi, Y., Komatsu, M., Futamura, H., \& Mihira, T. (2016). Macroeconomic Stabilisation and Monetary Policy of Four Asian Countries: Japan, Korea, Indonesia, and the Philippines. Targets, Effectiveness and Results. Economic Analysis series, 145, pp. 81. DOI: http://doi.org/10.21272/mmi.2018.2-10

Li, F., Li, Qin W., Qin, J., \& Ma, H. (2018). Identifying Eco-nomic Growth Convergence Clubs and G. Their Influencing Factors in China. Sustainability, 10 (8), pp. 2588. DOI: http://doi.org/10.3390/su 10082588

Matthews, J., Munday, M., Roberts, A., Williams, A., Christie, M., \& Midmore, P. (2003). An Index of Sustainable Economic Welfare for Wales: 1990-2000. Cardiff: Cardiff Business School.

Perotti, R. (1996). Growth, Income Distribution, and Democracy: What the Data Say. Journal of Economic Growth, 1 (2), pp. 149187. DOI: http://doi.org/10.1007/BF001388 61

Rocchetta, S., \& Mina, A. (2019). Technological coherence and the adaptive resilience of regional economies. Regional Studies, 53 (10), pp. 1421-1434. DOI: http://doi.org/ 10.1080/00343404.2019.1577552

Uryszek, T. (2015). Sustainable public finance - illusion or reality? Evidence from old EU member states. Journal of International Studies, 8 (1), pp. 22-30.

Тетяна Юріївна Коритько, канд. екон. наук, доиент Інститут економіки промисловості НАН України вул. Марії Капніст, 2, м. Київ, 03057, Україна E-mail: taniakorytko@gmail.com https://orcid.org/0000-0002-4251-1971;

Олена Миколаївна Крук, канд. екон. наук, доиент Донбаська державна машинобудівна академія вул. Академічна, 72, м. Краматорськ, 84313, Україна E-mail: 1k21061496@gmail.com https://orcid.org/0000-0002-5659-6603

\section{МОДЕЛЮВАННЯ ВПЛИВУ ІНВЕСТИЦІЙНӦ̈ АКТИВНОСТІ ПІДПРИЕМСТВ НА РІВЕНЬ СТАЛОГО РОЗВИТКУ РЕГІОНУ 3 ВИКОРИСТАННЯМ АПАРАТУ НЕЧІТКОЇ ЛОГІКИ}

У статті досліджено суть сталого розвитку регіону. Визначено, що його досягнення можливе за умови здійснення трансформацій та змін на підприємствах, в установах, органі- 
заціях, які функціонують на території цього регіону. Доведено, що рівень сталого розвитку регіону залежно від інвестиційної активності підприємств ураховує такі простори: економічний, територіальний, адміністративний, демографічний, інституційний, організаційний. Кожен із них можна оцінити з використанням показників, які характеризують особливості розвитку регіону.

Метою статті є розроблення науково-методичного підходу до моделювання впливу інвестиційної активності підприємств на рівень сталого розвитку регіону.

Запропонований підхід до моделювання впливу інвестиційної активності підприємств на сталий розвиток регіону дає змогу: проаналізувати кількісні показники складових елементів, визначити стан і рівень розвитку кожного окремого елемента, що значно підвищує ефективність формування необхідного організаційного забезпечення.

На основі апарату нечіткої логіки розроблено ієрархічну модель оцінювання рівня сталого розвитку регіону з урахуванням інвестиційної активності підприємств, яка дозволяє використовувати експертну інформацію про об'єкт дослідження у вигляді логічних правил; синтезувати кількісні показники в єдиний інтегральний показник структурних елементів системи. Перевагою запропонованого способу є його універсальність використання.

Тестування запропонованої моделі оцінювання впливу інвестиційної активності підприємств на рівень сталого розвитку регіону продемонстровано на прикладі Донецької області. Встановлено, що рівень сталого розвитку регіону на основі інвестиційної активності підприємств Донецької області впродовж 2018-2020 pp. є задовільним. Разом із тим спостерігається погіршення значення показника, що потребує коригування стратегічних орієнтирів розвитку регіону.

Ключові слова: моделювання, регіон, стійкість, інвестиційна активність, підприємство, розвиток.

JEL: C54; E52; O32; R12

Татьяна Юрьевна Корытько, канд. экон. наук, доцент Институт экономики промышленности НАН Украины ул. Марии Капнист, 2, г. Киев, 03057, Украина E-mail: taniakorytko@gmail.com https://orcid.org/0000-0002-4251-1971;

Елена Николаевна Крук, канд. экон. наук, дочент Донбасская государственная машиностроительная академия ул. Академическая, 72, г. Краматорск, 84313, Украина

E-mail: 1k21061496@gmail.com https://orcid.org/0000-0002-5659-6603

\section{МОДЕЛИРОВАНИЕ ВЛИЯНИЯ ИНВЕСТИЦИОННОЙ АКТИВНОСТИ ПРЕДПРИЯТИЙ НА УРОВЕНЬ УСТОЙЧИВОГО РАЗВИТИЯ РЕГИОНА С ИСПОЛЬЗОВАНИЕМ АППАРАТА НЕЧЕТКОЙ ЛОГИКИ}

В статье исследована сущность устойчивого развития региона. Отмечено, что его достижение возможно при условии проведения трансформаций и изменений на предприятиях, в учреждениях, организациях, функционирующих на территории этого региона. Доказано, что уровень устойчивого развития региона в зависимости от инвестиционной активности предприятий учитывает следующие пространства: экономическое, территориальное, административное, демографическое, институциональное, организационное. Каждое из них можно оценить с использованием показателей, характеризующих особенности развития региона. 
Целью статьи является разработка научно-методического подхода к моделированию влияния инвестиционной активности предприятий на уровень устойчивого развития региона.

Предложенный подход к моделированию влияния инвестиционной активности предприятий на устойчивое развитие региона позволяет: проанализировать количественные показатели составляющих элементов, определить состояние и уровень развития каждого отдельного элемента, что значительно повышает эффективность формирования необходимого организационного обеспечения.

На основе аппарата нечеткой логики разработана иерархическая модель оценки уровня устойчивого развития региона с учетом инвестиционной активности предприятий, которая позволяет использовать экспертную информацию об объекте исследования в виде логических правил; синтезировать количественные показатели в единый интегральный показатель структурных элементов системы. Преимуществом предлагаемого способа является его универсальность использования.

Тестирование предложенной модели оценки влияния инвестиционной активности предприятий на устойчивое развитие региона продемонстрировано на примере Донецкой области. Установлено, что уровень устойчивого развития региона на основе инвестиционной активности предприятий Донецкой области в течение 2018-2020 гг. является удовлетворительным. Вместе с тем наблюдается ухудшение значения показателя, что требует корректировки стратегических ориентиров развития региона.

Ключевые слова: моделирование, регион, устойчивость, инвестиционная активность, предприятие, развитие.

JEL: C54; E52; O32; R12

Формат ичитування:

Korytko T. Yu., Kruk O. M. (2021). Modelling an impact of enterprises' investment activity on the level of a region's sustainable development using fuzzy logic apparatus. Економіка промисловості. № 4 (96). C. 41-55. DOI: http://doi.org/10.15407/econindustry2021.04.041

Korytko, T. Yu., \& Kruk, O. M. (2021). Modelling an impact of enterprises' investment activity on the level of a region's sustainable development using fuzzy logic apparatus. Econ. promisl., 4 (96), pp. 41-55. DOI: http://doi.org/10.15407/econindustry2021.04.041

Надійшла до редакиії 01.10.2021 p. 